\title{
Przepis na wychowanie w świetle korespondencji rodziny Bnińskich
}

\begin{abstract}
Abstrakt. A recipe for upbringing according to the Bniński family
An analysis has been carried out of several dozen letters written between 13 August 1876 and 5 May 1890 by Roman Bniński (the father), addressed mainly to his son, Roman.

The analysed letters allow us to gain some insight, no matter how minimal, into the father's attitude towards his son, which is expected to shape his offspring. Not surprisingly, the correspondence reflects acceptance, cooperation, reasonable freedom and recognition of the child's rights.

In general, letters are a direct source presenting a family's everyday life, relations between family members, family affinities and relations with neighbours, acquaintances and friends... This is all reflected in the letters written by Roman Bniński to his son. Like all direct written sources, the letters provide a new image of the landed gentry, which is confronted with its stereotypical images, mainly formed on the basis of Positivistic and Marxist literature.
\end{abstract}

Keywords: Roman Bniński, the Bniński family, letter, father, son

„Prośba dziecka”, czyli 20 przykazań dla rodziców:

1. Nie psuj mnie. Dobrze wiem, że nie powinienem mieć tego wszystkiego, czego się domagam. To tylko próba sił z mojej strony.

2. Nie bój się stanowczości. Właśnie tego potrzebuję - poczucia bezpieczeństwa.

3. Nie bagatelizuj moich złych nawyków. Tylko ty możesz pomóc mi zwalczyć zło, póki jest to jeszcze w ogóle możliwe.

4. Nie rób ze mnie większego dziecka, niż jestem. To sprawia, że przyjmuje postawę głupio dorosłą.

5. Nie zwracaj mi uwagi przy innych ludziach, jeśli nie jest to absolutnie konieczne. O wiele bardziej przejmuję się tym, co mówisz, jeśli rozmawiamy w cztery oczy. 
6. Nie chroń mnie przed konsekwencjami. Czasami dobrze jest nauczyć się rzeczy bolesnych i nieprzyjemnych.

7. Nie wmawiaj mi, że błędy, które popełniam, są grzechem. To zagraża mojemu poczuciu wartości.

8. Nie przejmuj się za bardzo, gdy mówię, że cię nienawidzę. To nie ty jesteś moim wrogiem, lecz twoja miażdżąca przewaga!

9. Nie zwracaj zbytniej uwagi na moje drobne dolegliwości. Czasami wykorzystuję je, by przyciągnąc twoją uwagę.

10. Nie zrzędź. W przeciwnym razie muszę się przed tobą bronić i robię się głuchy.

11. Nie dawaj mi obietnic bez pokrycia. Czuję się przeraźliwie tłamszony, kiedy nic $\mathrm{z}$ tego wszystkiego nie wychodzi.

12. Nie zapominaj, że jeszcze trudno mi jest precyzyjnie wyrazić myśli. To dlatego nie zawsze się rozumiemy.

13. Nie sprawdzaj z uporem maniaka mojej uczciwości. Zbyt łatwo strach zmusza mnie do kłamstwa.

14. Nie bądź niekonsekwentny. To mnie ogłupia i wtedy tracę całą moją wiarę w ciebie.

15. Nie odtrącaj mnie, gdy dręczę cię pytaniami. Może się wkrótce okazać, że zamiast prosić cię o wyjaśnienia, poszukam ich gdzie indziej.

16. Nie wmawiaj mi, że moje lęki są głupie. One po prostu są.

17. Nie rób z siebie nieskazitelnego ideału. Prawda na twój temat byłaby w przyszłości nie do zniesienia. Nie wyobrażaj sobie, iż przepraszając mnie stracisz autorytet. Za uczciwą grę umiem podziękować miłością, o jakiej nawet ci się nie śniło.

18. Nie zapominaj, że uwielbiam wszelkiego rodzaju eksperymenty. To po prostu mój sposób na życie, więc przymknij na to oczy.

19. Nie bądź ślepy i przyznaj, że ja też rosnę. Wiem, jak trudno dotrzymać mi kroku w tym galopie, ale zrób, co możesz, żeby nam się to udało.

20. Nie bój się miłości. Nigdy ${ }^{1}$

Historia ziemiaństwa polskiego stała się w ostatnich trzech dziesięcioleciach dla polskich badaczy, nie tylko atrakcyjnym polem badawczym, ale również i niezwykle ważnym. Należy jednak podkreślić, że jest to tematyka trudna do opracowania ${ }^{2}$. Andrzej Kwilecki pisał bowiem:

historia ziemiaństwa polskiego [...] jest tematem atrakcyjnym [...] ze względu na miejsce zajmowane niegdyś przez ziemian w hierarchii spotecznej oraz wielość ról odgrywanych przez ich przedstawicieli $w$ życiu publicznym. Tematem ważnym - ponieważ żadnego $z$ dziejacych się w owej epoce procesów spolecznych ni następujących po sobie w życiu narodu i państwa do-

\footnotetext{
${ }^{1} \mathrm{http}: / /$ swiadomaedukacja.pl [dostęp: 18.07.2018].

${ }^{2}$ A. Kwilecki, Żywe jest zainteresowanie problematyka ziemiańska. Zamiast wstępu, w: Ziemiaństwo wielkopolskie. W kręgu arystokracji, A. Kwilecki (red.), Poznań 2004, s. 13.
} 
niostych wydarzeń nie da się w petni opisać czy wyjaśnić bez ukazania roli ziemiaństwa. Z kolei temat jest trudny, nawet bardzo trudny, ponieważ wieki XIX i XX (do 1945 r) nie sq epoka jednolita; okres ten składa się z szeregu epok historycznych, w których: (a) wielce zmieniaty się warunki życia ziemian $i$ ich rola $w$ procesach spolecznych i politycznych; (b) stopniowemu kurczeniu ulegała baza majątkowa wystawy ziemiańskiej; (c) w strukturze ziemiaństwa, poczatkowo jednolitego pod względem pochodzenia (szlacheckiego), zwiększały się udziaty ludzi i rodzin o pochodzeniu nieszlacheckim czy etnicznie obcym; (d) narosły duże różnice między ziemianami żyjacymi w trzech zaborach; (e) baza źródłowa do badań nad ziemiaństwem uległa $w$ czasie $i$ w wyniku II wojny światowej oraz zmian ustrojowych poważnemu uszczupleniu bądź rozproszeniu ${ }^{3}$.

Mimo tych trudności, wzrost zainteresowania ziemiaństwem znalazł wymierne przełożenie na liczbę publikowanych w ostatnich latach materiałów źródłowych. Należy podkreślić, że mają one zróżnicowany charakter. Zaliczymy bowiem do nich przede wszystkim pamiętniki, wspomnienia oraz listy osób zaliczających się do warstwy ziemiańskiej Jednak mimo zintensyfikowania badań, historię ziemiaństwa polskiego nadal charakteryzują luki faktograficzne. Są one wynikiem wielu wypadkowych. Wydaje się, że najważniejszą z nich jest konieczność nasilenia badań archiwalnych, których następstwem jest dostęp do niewykorzystywanych dotąd źródeł.

Kwerenda w Archiwum w Winnicy (Ukraina), umożliwiła pozyskanie wielu materiałów źródłowych ukazujących życie codzienne ziemiaństwa podolskiego. Konstruowanie obrazu ziemiaństwa umożliwiła lektura m.in. listów Romana Bnińskiego ${ }^{5}$ do syna również Romana Bnińskiego ${ }^{6}$.

Analizie poddano kilkadziesiąt listów powstałych między 13 sierpnia 1876 r. a 5 maja 1890 r. Listów adresowanych przede wszystkim do syna Romana. Należy jednak zaznaczyć, że w tym zbiorze znajduje się również list adresowany równocześnie do dwóch synów: Romana i Hilarego?

Rozpatrywane listy powstały w okresie, gdy rodzina Bnińskich mieszkała w Krakowie ${ }^{8}$. W okresie, gdy Roman i Hilary, pobierali naukę w tamtejszych szkołach, co uniemożliwiało

${ }^{3}$ Ibidem, s. 13-14.

4 Ibidem.

5 Zob: M. Janik, Bniński Roman (1826-1912), w: Polski słownik biograficzny, t. II, Kraków 1936, s. 47148; M. Miszczuk, Bniński Roman Piotr herbu Łodzia (1869-1948), w: Harcerski Słownik biograficzny, t. IV, J. Wojtycza (red.), Warszawa 2016, s. 36; M. J. Minakowski, Genealogia potomków Sejmu Wielkiego, http:// www.sejm-wielki.pl/b/1.1122.113 [dostęp: 1.06.2018].

${ }^{6}$ Zob: S. Sedlaczek, Harcerstwo na Rusi i $w$ Rosji: 1913-1920, Warszawa 1936; M. Korzeniowski, Za Złota Brama. Działalność społeczno-kulturalna Polaków w Kijowie w l. 1905-1920, Lublin 2009; M. Miszczuk, op. cit., s. 36-37; M.J. Minakowski, Genealogia potomków Sejmu Wielkiego, http://www.sejm-wielki. pl/b/1.1122.117 [dostęp: 1.06.2018]; A. Ziaja, Wybrane przejawy aktywności społeczno-kulturalnej Polaków na Ukrainie Naddnieprzańskiej w okresie rządów ukraińskiej Rady Centralnej (marzec 1917 - kwiecień 1918), http://www.irekw.internetdsl.pl/aktywucr.html [dostęp: 1.06.2018].

${ }^{7}$ Archiwum Obwodowe w Winnicy, Spuścizna rodziny Bnińskich, bez sygnatury, List Romana Bnińskiego do synów Romana i Hilarego Bnińskich, 11 maja [18]83 Gastein. Vide: M. Miszczuk, op. cit., s. 36.

${ }^{8}$ M. Janik, op. cit., s. 148. 

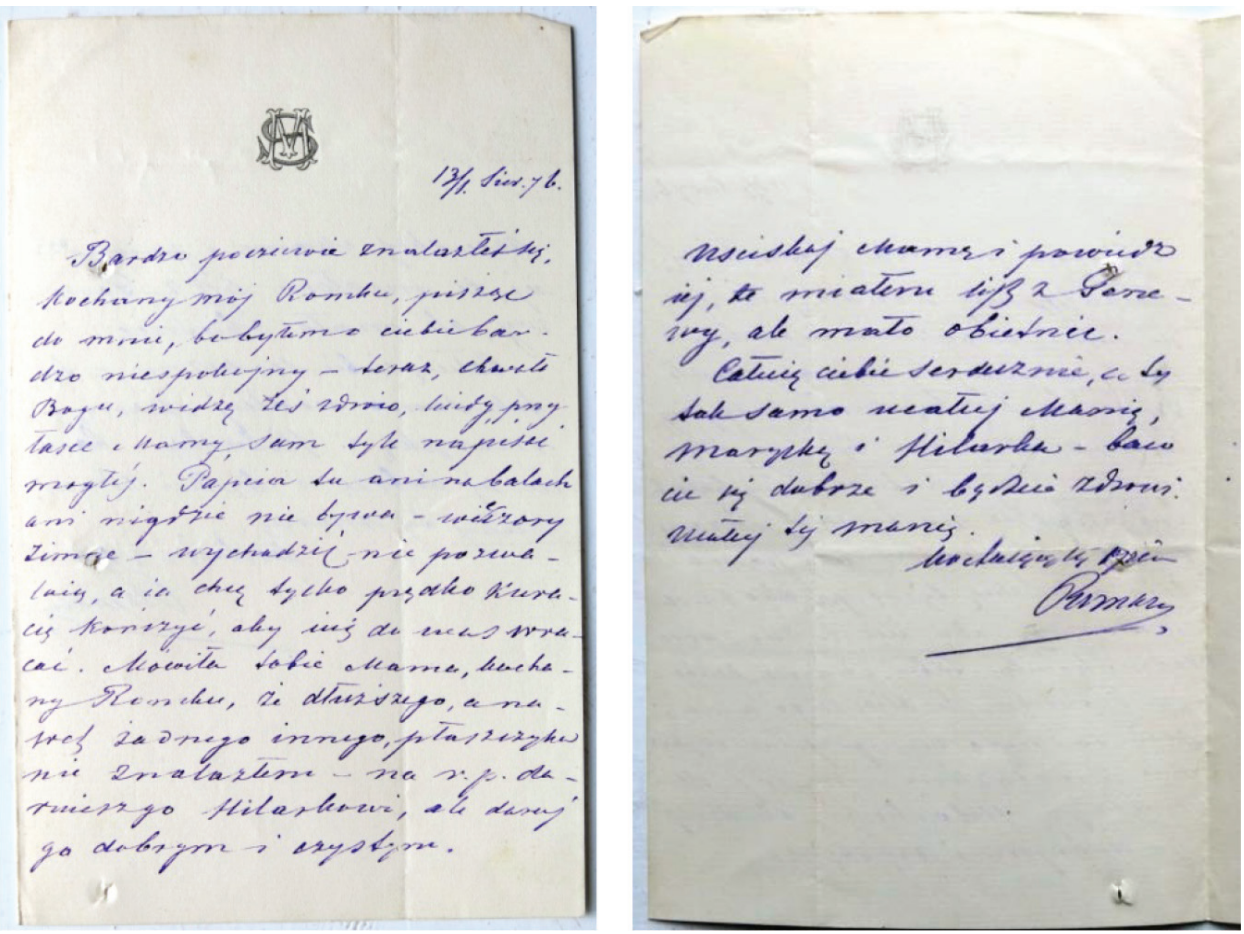

Fot. 1-2. List Romana Bnińskiego do syna Romana Bnińskiego

Źródło: Archiwum Obwodowe w Winnicy, Spuścizna rodziny Bnińskich, bez sygnatury, List Romana Bnińskiego do syna Romana Bnińskiego, 13/1 Sier[pnia] [18]76.

rodzinie wspólne podróżowanie. Ówczesny model edukacji był tradycyjny. Matka była odpowiedzialna za organizację opieki nad dziećmi. Miała również zapewnić podstawy kształcenia. Stąd też najczęściej do 12-14 roku nauka odbywała się w domu. Po tym okresie chłopcy podejmowali edukację w gimnazjum ${ }^{9}$. Wynikało to z przekonania, że nawet najlepsza edukacja domowa nie może zastąpić nauki w szkole. Nauka szkolna miała zapewnić uniwersalną wiedzę. Wiedzę ,jaką ludzie dobrze wychowani mieć powinni”. Nauka szkolna miała być bowiem wprowadzeniem do życia. Miała przede wszystkim uczyć obcowania z ludźmi. Panowało bowiem wówczas przekonanie, że jeśli się nauczysz stuchać i powodować się starszymi za młodu potrafisz później jak wyrośniesz drugim rozkazywaćio.

9 T. Epsztein, Edukacja dzieci i młodzieży w polskich rodzinach ziemiańskich na Wolyniu, Podolu i Ukrainie w II połowie XIX wieku, Warszawa 1998, s. 37-51.

10 Ibidem, s. 52. 


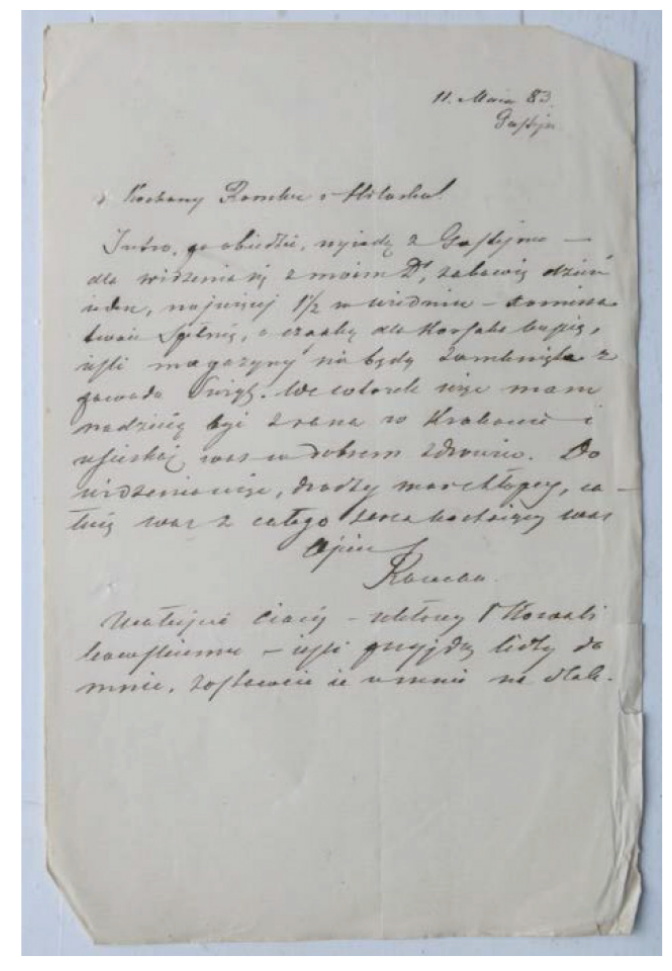

Fot. 3. List Romana Bnińskiego do synów Romana i Hilarego

Źródło: Archiwum Obwodowe w Winnicy, Spuścizna rodziny Bnińskich, bez sygnatury, List Romana Bnińskiego do synów Romana i Hilarego Bnińskich, 11 maja 83 Gastein.

Roman Bniński podjął naukę w Krakowie. Uczęszczał (kolejno) do: I Gimnazjum św. Anny, II Gimnazjum św. Jacka oraz III Gimnazjum im. kr. Jana III Sobieskiego. Do egzaminu maturalnego - pierwszy raz - przystąpił w czerwcu 1888 r. Jednak go nie zdał. Ponownie do egzaminu przystąpił we wrześniu tegoż roku. Te drugie egzaminy udało mu się zaliczyć. Maturę uzyskał zatem w terminie jesiennym. Podjął studia na Wydziale Filozoficznym Uniwersytetu Jagiellońskiego. Studiował również w Studium Rolniczym Uniwersytetu Jagiellońskiego. W lipcu 1891 r. zdał egzamin rolniczy ${ }^{11}$.

Kwerenda archiwalna umożliwiła eksplorację tylko listów ojca do syna. Dlatego też analizowane listy pozwoliły jedynie na scharakteryzowanie postaw ojca wobec syna. Postaw, które miały kształtować/wychowywać syna.

${ }^{11}$ M. Miszczuk, op. cit., s. 36. 


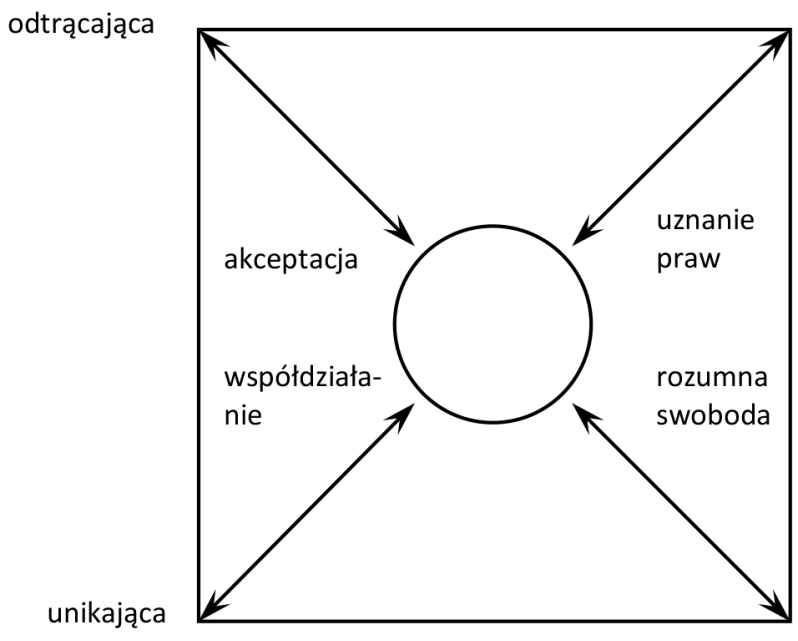

nadmiernie

wymagająca

nadmiernie

chroniąca

Rys. Model właściwych i niewłaściwych typologii postaw rodzicielskich

Źródło: M. Ziemska, Postawy rodzicielskie i ich wpływ na osobowość dziecka, w: Rodzina i dziecko, M. Ziemska (red.), Warszawa 1980, s. 182.

Współczesna nauka dysponuje wieloma zestawieniami postaw rodzicielskich ${ }^{12}$. Do analizy listów Romana Bnińskiego wykorzystano model zaprezentowany w pracy Rodzina i dziecko, wydanej pod redakcją Marii Ziemskiej ${ }^{13}$.

Rysunek przedstawia właściwe i niewłaściwe postawy rodzicielskie oraz ich wzajemne powiązania. Do właściwych (zaprezentowanych na obwodzie koła) zaliczono: akceptację, współdziałanie, rozumną swobodę i uznanie praw dziecka. Wierzchołki kwadratu określają natomiast główne typy niewłaściwych postaw. Zaliczono do nich: unikanie kontaktu z dzieckiem, odtrącanie dziecka, nadmierne wymagania wobec dziecka oraz nadmierne chronienie go ${ }^{14}$.

W listach Romana Bnińskiego do syna odnajdziemy jedynie postawy właściwe. Narracja listów wskazuje, że najważniejszą postawą cechującą listy ojca, była postawa zdefiniowana jako akceptacja.

12 Najważniejsze typologie postaw rodzicielskich odnajdziemy w tekście Marii Ziemskiej pt. Postawy rodzicielskie i ich wplyw na osobowość dziecka, zob.: M. Ziemska, Postawy rodzicielskie i ich wptyw na osobowość dziecka, w: Rodzina i dziecko, M. Ziemska (red.), Warszawa 1980, s. 184-191.

13 Ibidem, s. 182 i n.

14 Ibidem, s. 184-191. 

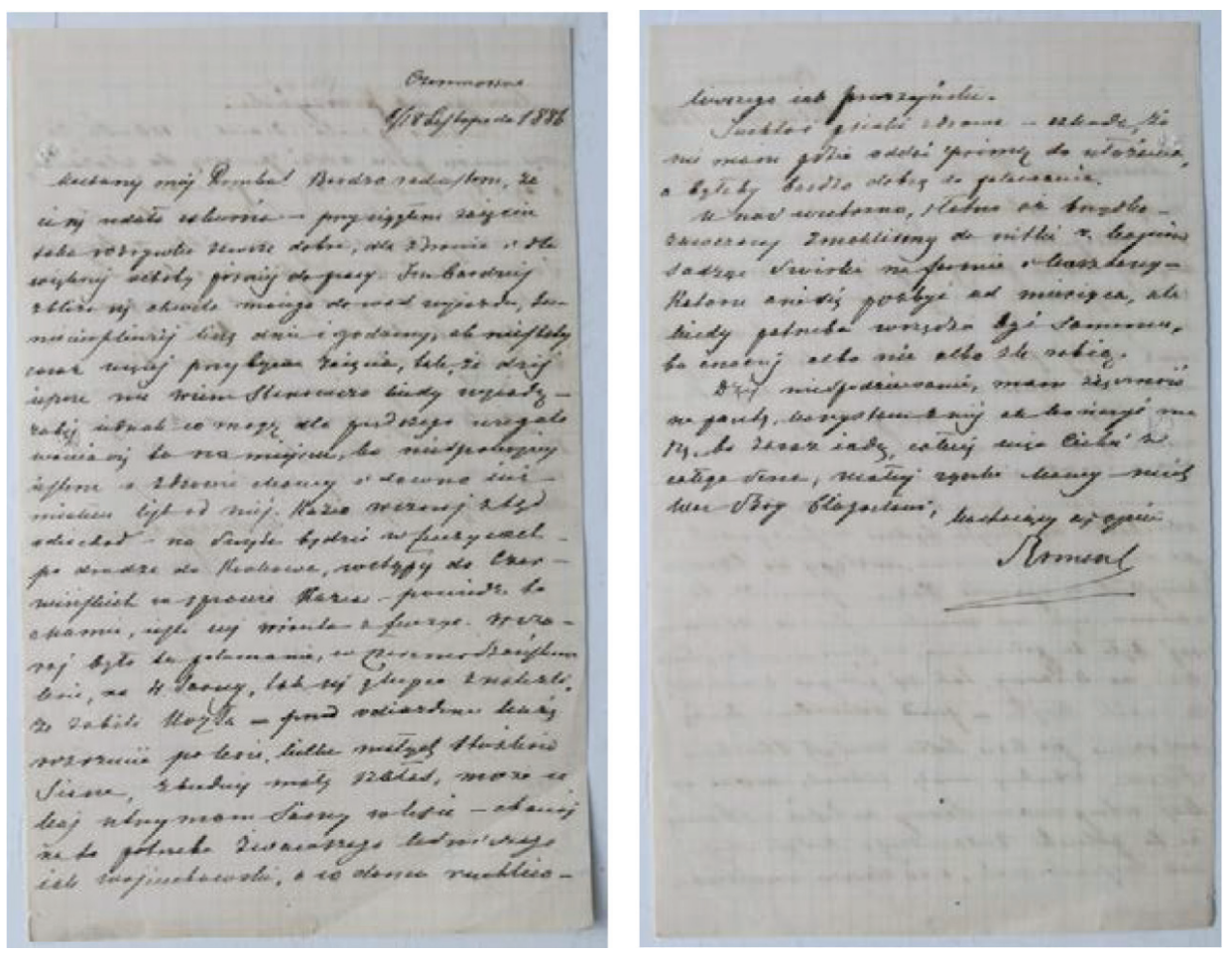

Fot. 4-5. List Romana Bnińskiego do syna

Źródło: Archiwum Obwodowe w Winnicy, Spuścizna rodziny Bnińskich, bez sygnatury, List Romana Bnińskiego do syna Romana Bnińskiego, 6/18 Listopada 1886 Czeremoszno.

M. Ziemska pisała: akceptacja dziecka polega na przyjęciu dziecka takim, jakie ono jest z jego cechami wygladu fizycznego, usposobienia, umysłowymi możliwościami $i$ łatwościa osiagnięć w jednych dziedzinach, a ograniczeniami i trudnościa osiagania powodzenia w innych. Akceptujacy rodzice rzeczywiście lubi swoje dziecko i nie ukrywaja przed nimi tego uczucia ${ }^{15}$. Niestety listy ojca, nie dostarczają nam informacji na temat większości z wymienionych kategorii. Nie zostawiają żadnych jednak wątpliwości, że ojciec kocha syna. Roman Bniński nie krył swoich uczuć. Już bowiem w pieszym badanym liście pisze, że syna kocha ${ }^{16}$.

15 Ibidem, s. 184.

${ }^{16}$ Archiwum Obwodowe w Winnicy, Spuścizna rodziny Bnińskich, bez sygnatury, List Romana Bnińskiego do syna Romana Bnińskiego, 13/1 Sier[pnia] [18]76. 
Akceptacja przekłada się również na kontakt rodzica z dzieckiem ${ }^{17}$. Listy Romana Bnińskiego wskazują, że ojciec był zadowolony z kontaktu z dzieckiem. Ojciec niemal w każdym liście podkreśla chęć łączności z synem/synami. Ze względu na okoliczności kontakt ten został jednak ograniczony jedynie do wymiany korespondencji.

Roman Bniński w pierwszych zdaniach pisanych przez siebie listów dziękuje dziecku za otrzymaną korespondencję. Owe podziękowania mają różną objętość. Odnajdziemy bowiem podziękowania krótkie ${ }^{18}$ oraz rozbudowane ${ }^{19}$. Na szczególną uwagę zasługuje druga ich grupa, gdyż ma ona charakter złożony. Zawiera ona podziękowanie wraz z opisem emocji, które towarzyszą ojcu jako adresatowi listu. Odnajdziemy w nich m.in. troskę o dziecko ${ }^{20}$, radośćc ${ }^{21}$ oraz dumę ${ }^{22}$.

Ojciec, dbając o kontakt listowny, starał się go podtrzymywać. Dlatego też przede wszystkim nie zwlekał z odpowiedzią. Odnajdziemy zatem w listach zwroty, które wskazują, że odpisywał na listy syna tego samego dnia ${ }^{23}$, dnia następnego lub w najbliższej możliwej chwili ${ }^{24}$. Opóźnienia miały różne przyczyny ${ }^{25}$.

Bniński w tekście swoich listów wskazuje, że komunikacji za pośrednictwem listów bywa bardzo często utrudniona przez czynniki zewnętrzne. Nie zawsze korespondencja była bowiem dostarczana tak szybko, jakby tego sobie życzyli nadawca i odbiorca ${ }^{26}$.

${ }^{17}$ M. Ziemska, op. cit., s. 184.

18 Pisał: „Bardzo ci dziękuję za twój list” - Archiwum Obwodowe w Winnicy, Spuścizna rodziny Bnińskich, bez sygnatury, List Romana Bnińskiego do syna Romana Bnińskiego, 16/28 Lut[ego] 1886 Kijów.

19 Pisał: „Kochany Romku! Po wyprawieniu dziś listu do Mamy, przywieźli mi z poczty list od Mamy i od ciebie. Rad jestem, że się bawisz, w przerwie od nauki i że znalazłeś czas pisania do mnie, bo każda od was wiadomość bardzo pożądana" - ibidem, 8/20 Paźdz[iernika] Czeremoszno.

20 Pisał: „Bardzo poczciwie znalazłeś się, kochany mój Romku, pisząc do mnie, bo byłem o ciebie bardzo niespokojny - teraz, chwała Bogu, widzę żeś zdrów, kiedy przy łasce, karny sam tyle napisać mogłeś" - ibidem, 13/1 Sier[pnia] [18]76.

21 Pisał: „Serdecznie ci dziękuję, kochany mój Romku, za twój poczciwy liścik” - ibidem, 28. Maja 1879.

22 Pisał: „Serdecznie ci dziękuję, kochany mój Romku, za twój poczciwy liścik - tym bardziej mnie ucieszył, że wcale dobrze napisany. Chciałbym już jak najprędzej być z wami - zaraz też po ostatniej kąpieli, wyjeżdżam do Krakowa. Rad jestem żem tak wcześnie pojechał do Gastein - bo całe wakacje będę mógł zostać z wami, chyba by mnie do kraju puścili - o czem wątpię" - ibidem, 28. Maja 1879.

${ }^{23}$ Pisał: „Dziś mi twój list oddano i zaraz odpisuję aby ci za to pisanie podziękować” - ibidem, 17. maja 86. Gostyń.

${ }^{24}$ Pisał: „Zawczoraj odebrałem twój list, z opisem świetnych myśliwskich powozów, a dziś naraz z tem pisaniem do ciebie" - ibidem, 6/18 Września [18]85 Czeremoszno.

25 Pisał: „Dziś odebrałem ostatni twój list z 17/29 bm. - bardzo ucieszony byłem tą twoją poczciwością, przy twoich obecnych zajęciach nie spodziewałem się abyś na to miał czas, dla tego tem serdeczniej dziękuję tobie, kochany Romku" - ibidem, 24 Września/6 Października 1887 Wacławówka.

${ }_{26}$ Pisał: „Ani Mamy, ani ciebie nie obwiniam o niepisanie - wina to tutejszego pocztowego zarządu wszak ostatni twój list wczoraj mi oddano - oblicz ile dni był w drodze - trudno się z tem oswoić, stąd często niepokój o was, moi drodzy" - ibidem, 8/20 Kwietnia 1888 Wacławówka. 
Jedną z przyczyn tego stanu rzeczy był sposób funkcjonowania poczty ${ }^{27}$. Jednak, aby listy otrzymywać, to najpierw musiały zostać napisane, a syn nie zawsze pisał listy systematycznie. Dlatego też, kolejną przyczyną była niefrasobliwość syna ${ }^{28}$.

Rodzic był tak spragniony korespondencji od dziecka, że gani go za brak kontaktu ${ }^{29}$. Należy podkreślić, że ojciec potrafił być też wyrozumiały w tej kwestii. Gdy syn miał natłok obowiązków, wykazywał w tej kwestii wyrozumiałość. Sam nalegał, by syn nie pisał zbyt często listów ${ }^{30}$.

Jednak nawet bardzo częsta korespondencja nie była w stanie zastąpić kontaktu osobistego $^{31}$. Stąd też narracja listów wskazuje, że ojciec bardzo tęsknił za kontaktem bezpośrednim. Był on jednak utrudniony przez: obowiązki zarządcze ${ }^{32}$ oraz uwarunkowania zdrowotne $^{33}$. Zapewne dlatego też uznał, że najlepszym odzwierciedleniem dnia codziennego byłby dziennik, choć równocześnie podkreślił, że byłby to jednostronny kontakt, co widocznie mu nie odpowiadało ${ }^{34}$. Zatem pielęgnowanie przez ojca kontaktu z synem pozwala wnioskować, że obcowanie z dzieckiem (choć tylko korespondencyjne) sprawia rodzicowi przyjemność i zadowolenie.

27 Pisał: „List twój odebrałem na wyjezdnem, dla tego nie odpowiedziałem zaraz, chociaż ochoty nie brakowało, bo to się tobie należało za wcale dobrze napisany list. Dziś odpowiedź wysyłam z domu - nie ręczę czy nie odbierzesz ją po moim dopiero powrocie do was - ale to już nie moja będzie wina - tutejsze porządki pocztowe niełatwo zmienić" - ibidem, 4/16 Marca [18]86 Czeremoszno.

${ }_{28}$ Pisał: „Oprócz jednego listu z domu a drugiego od kochanej Mamy, nic nie odebrałem - a ty piszesz, kochany Romku, żeś mi lista wysłał - a gdzież by się podziały? U nas to się często trafia, ale tu przecie - nie. Jeśliś miał wysłać a zapomniałeś - nie wielka bieda - w czasie kuracji unikam interesów - to odeślij mi je już do Wiednia, abym się nie rozminął" - ibidem, 17. maja [18]86. Gostyń.

${ }_{29}$ Pisał: „Kochany mój Romku! Wolałbym nigdy nie mieć nic do zarzucenia tobie, ale, wiedząc z pewnością, że zawsze chętnie przyjmujesz każdą uwagę i każdą radę, tym razem muszę ci powiedzieć, iż w ciągu 3 dni czasu od przyjazdu Dmytra do wyjazdu jego wprost do Czeremosznego, powinieneś był choć kilka słów do mnie napisać - wiesz przecie jak zawsze jestem o was niespokojny, przy braku wiadomości. Na ten raz dosyć wiem, że na przyszłość będziesz uważniejszy" - ibidem, 28/9 Sier[pnia]/W[rześnia] Czeremoszno.

30 Pisał: „List twój ostatni wczoraj mi oddano - do matury zwalniam ciebie zupełnie od pisania, mój Romku - nadto masz zajęcia - wolną chwilkę lepiej użyj na spacer, na rozrywkę - matura konieczna, ale nie łatwa, co nie przeszkadza abyś o zdrowiu myślał. W br. wakacje twoje będą o wiele dłuższe - wypoczniesz, odżywisz się wiejskim powietrzem, ale zawsze lepiej przyjechać zupełnie zdrowym” - ibidem, 25 Kwietnia/ 7 Maja 1888 Wacławówka.

31 Pisał: „Nie wesoło to być samemu w domu, mój Romku - tęskno za wami - gospodarka zająć może i powinna, to prawda, ale domowe, drobne zajęcia, myślenie o kuchni, itp., calamitate par trop [nadmiar nieszczęścia]" - ibidem, 9/21 Marca 1887 Czeremoszno.

32 Pisał: „nadzieję na początku Czerwca wpaść do was choć na dni kilka - bo w polu, do żniw, nie będzie już roboty, oprócz orania" - ibidem, 8/20 Kwietnia 1888 Wacławówka.

33 Pisał: „Chciałbym już jak najprędzej być z wami - zaraz też po ostatniej kąpieli, wyjeżdżam do Krakowa. Rad jestem żem tak wcześnie pojechał do Gastein - bo całe wakacje będę mógł zostać z wami, chyba by mnie do kraju puścili - o czem wątpię" - ibidem, 28. Maja 1879.

${ }^{34}$ Pisał: „Wolałbym i ja do ciebie, kochany Romku, i do Mamy pisać w formie dziennika - byłaby to codzienna z wami rozmowa, ale stąd wysyłać dzienniczek, to chyba dla zamiany korespondencji na nudną i drażniącą gawędę" - ibidem, 14/26 Paździ[ernika] 1887 Wacławówka. 
Akceptacja dziecka polega również na jego aprobacie. Ojciec chwali syna ${ }^{35}$. Gdy zasłuży, potrafi zganić jego zachowanie ${ }^{36}$. Należy jednak podkreślić, że gani zachowanie, a nie dziecko jako osobę 37 .

Roman Bniński nie tylko akceptuje syna, ale stara się z nim współdziałać. Współdziałanie z dzieckiem dowodzi o zaangażowaniu na rzecz jego dobra. Ojciec wykazuje zainteresowanie różnymi aspektami życia syna. Stąd też interesuje go zarówno praca $^{38}$, relacje interpersonal$\mathrm{ne}^{39}$, jak i zabawa ${ }^{40}$. Ojciec angażuje również syna w sprawy rodziny ${ }^{41}$, rodziców ${ }^{42}$ oraz

35 Pisał: „Bardzo rad jestem, że w wiosce rzeczywistą korzyść znalazłeś - notuj wszystko, kochany Rom$\mathrm{ku}$ - sam wiesz jaki tu, u nas brak specjalnych wiadomości w rozmaitych gałęziach gospodarskich - a co dzień większa daje się czuć potrzeba, umieć ze wszystkiego skorzystać, nic nie opuścić co dochód powiększa - coraz ciężej - interesy trudne - ceny małe, koszta gospodarskie coraz większe - różnicą tą wypadnie może tylko korzystniejsza produkcja, w obrobieniu ziemi i w większej i lepszej co do ziarna produkcji” - ibidem, 18/30 Paźdz[iernika] [18]89. Wacławówka.

${ }^{36}$ Pisał: „Nic nie wiem o Adzie/Adziu? O Filimowskim, kto został przy was? Czy Hilarek wpisany? Kto go uczyć będzie? Pamiętaj, drogi Romciu, w domu nie rozmawiaj teraz inaczej (i Hilarek) jak po francusku inaczej nie nauczycie się, a tobie teraz trudno, mieć jeszcze kilka godzin lekcji prywatnych, a bez francuskiego i niemieckiego, bądź co bądź, trudno się obejść" - ibidem, 28 Sierp[nia]/9 Wrześ[nia] 1885. Czeremoszno.

37 M. Ziemska, op. cit., s. 184.

38 Pisał: „Na zakończenie tego pisania, kochany mój Romku, przypomnę tobie zbliżające się examina nie wątpię, że o nich pamiętasz - przypominam tylko dla tego, że w b.r. jako gimnazjalista musisz już być w Krakowie na termin, tj. 1 września - wakacje krótsze - można je tylko przedłużyć, przyśpieszając examin wyjeżdżając na wieś, gdziekolwiek posiedzicie, nie w końcu czerwca, a co najmniej 15 a to, t. te 2 tygodnie dłuższych wakacji, zależy od dobrego przygotowania się do examinu - bo Mama będzie zawsze w porę do wyjazdu gotową, aby was prędzej na wieś wyprawić, a więc z naszej strony przeszkodą nie będzie" - Archiwum Obwodowe w Winnicy, Spuścizna rodziny Bnińskich, bez sygnatury, List Romana Bnińskiego do syna Romana Bnińskiego, 4/16 Marca [18]86 Czeremoszno.

39 Pisał: „Zajście wasz w klasie naturalnie niepotrzebne i smutne - ale to zdarzało się i za moich czasów wątpię czy może być inaczej - zupełna jedność i zgoda nastąpi ogólnie chyba po trąbie Archanioła - to są przykrości, kochany Romku, tem boleśniejsze, że nie wasza w tem wina, ale to jeszcze nie uniemożliwia koleżeństwa, a robi go dziś może trudniejszem, ale też dziś, nie odstępując nigdy zasad uczciwości i honoru, trzeba być wyrozumialszym wobec prądów gorszych, jak za moich czasów, wobec spotykania na ławce szkolnej wszystkich warstw społecznych - dawniej tego nie było, a więc dziś bardziej jeszcze narażeni na stykanie się $\mathrm{z}$ różnymi pojęciami, przesądami, z różnymi nawet manierami - to utrudnia pozycję, ale i utrudniający często robi to bezwiednie, czasami bez złej myśli, a tylko pod wpływem innego wychowania, innych wyobrażeń, innego otoczenia, w którym od dzieciństwa żyje - to przecie nie jest jego winą, dlatego prędzej na uwzględnienie, jak na potępienie zasługuje - o tem pamiętać winniście. Ale za to stanowczo obwiniam przełożonego, który właśnie w takich razach obowiązany być mediatorem rozsądnym i sprawiedliwym, a nigdy czem innem. Żałuję, że nie będę na waszym wieczorku, to przez ciebie, mój Romku i wieczorek i oni mnie bardzo obchodzą" - ibidem, 14/26 Paździ[ernika] 1887 Wacławówka.

${ }^{40}$ Pisał: „rad bardzo jestem, że ci się tak świetnie udało polowanie, żałuję, żeś nie miał tej przyjemności w Czeremosznem, ale zawsze szczerze winszuję zabicia dzika - to już bardzo poważne wejście w szranki myśliwskie" - ibidem, 28 Sierp[nia]/9 Wrześ[nia] 1885. Czeremoszno.

${ }^{41}$ Pisał: „Pamiętaj, drogi Romciu, w domu nie rozmawiaj teraz inaczej (i Hilarek) jak po francusku - inaczej nie nauczycie się, a tobie teraz trudno, mieć jeszcze kilka godzin lekcji prywatnych, a bez francuskiego i niemieckiego, bądź co bądź, trudno się obejść" - ibidem, 28 Sierp[nia]/9 Wrześ[nia] 1885. Czeremoszno.

42 Pisał: „Powiedz Adasiowi (do niego nie piszę, nie wiedząc kiedy wraca) że rzeczy jego Ojca odszukałem - wyślę je przez kantor expedycyjny do Orenburga[?], albo ze sobą przywiozę - ale prawdopodobnie wyślę, ale tym razem przez pewną agenturę" - ibidem, 16/28 Lut[ego] 1886 Kijów. 


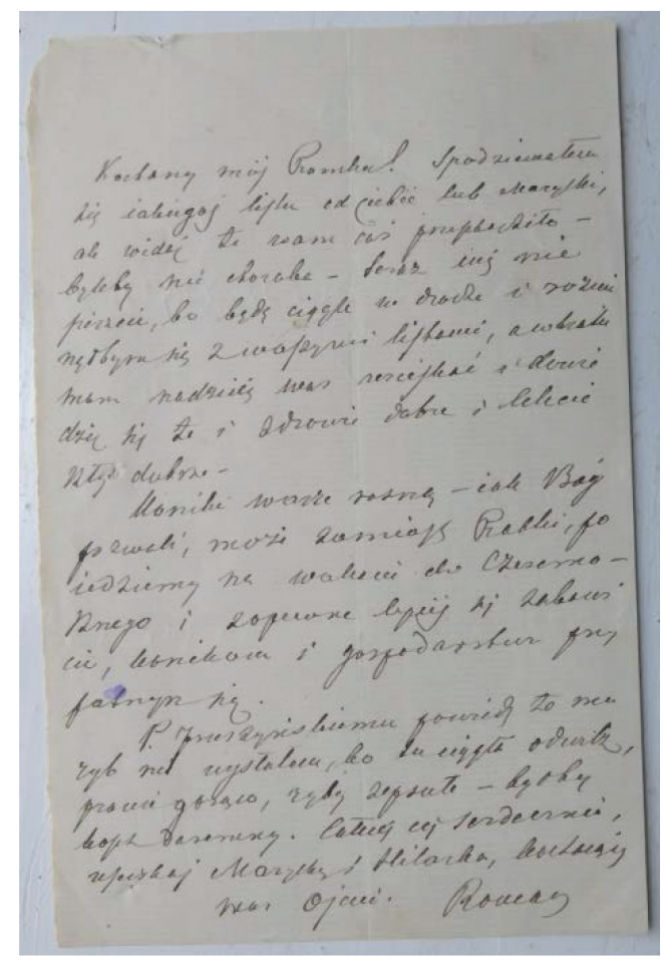

Fot. 6. List Romana Bnińskiego do syna

Źródło: Archiwum Obwodowe w Winnicy, Spuścizna rodziny Bnińskich, bez sygnatury, List Romana Bnińskiego do syna Romana Bnińskiego, brak daty, brak miejsca.

domu/majątku ${ }^{43}$. Jednak nie jest to działanie jednostronne, gdyż sam realizuje życzenia ${ }^{44}$ syna oraz dba o jego własnośćt5. Należy jednak podkreślić, że ojciec powierza synowi

43 Pisał: „Dziś puściłem młocarnię, którą układałeś - młóci znakomicie - jutro próba będzie całodzienna kierat już obwarowany, a więc na dobre zacznę młócić" - ibidem, 24 Września/6 Października 1887 Wacławówka.

${ }_{44}$ Pisał: „Wczoraj wysłałem list do Mamy, kochany Romku, a dziś odpisując na twoje pisanie, powiem ci, że miarę na łyżwy schowałem i jeśli tylko dostanę w Wiedniu, przywiozę je wam z tem, że bardzo uważnie i ostrożnie tą nową gimnastyką zabawiać się będziecie" - ibidem, 15 maja [18]82. Gastein.

45 Pisał: „Charty twoje bardzo urosły - każę brać je już na obróż, bo zaczynają się włóczyć - polowania w b.r. wzbroniłem i tu i w Malinkach[?] - jeśli będziecie mogli przyjechać, może tobie będzie się lepiej udawało jak w r. z.[roku zeszłym] Achillesa zostawisz w Krakowie - tu szukam dla ciebie dobrego konia do polowania, mocnego do jazdy, a nie drogiego, aby po wakacjach mógł pójść pod oficjalistę - bo na co darmozjada - Juchta Hilarkowi doskonale jeszcze służyć będzie - a do wózka jakaś para dobierze się - a jeśli przyjazd 
zadania odpowiednie do jego wieku, z zatem odpowiednie do jego możliwości i rozwoju ${ }^{46}$.

Kolejną pozytywną postawą jest uznanie praw. Roman Bniński uznaje prawa dziecka. Dlatego też akceptuje różne formy jego aktywności. Jednak aktywności dostosowanej do razy rozwojowej dziecka. Ojciec pozwala, by dziecko dziatato [...] na wtasna odpowiedzialnośćc ${ }^{47}$. Oczekuje dojrzałego zachowania ${ }^{48}$. Dlatego też kieruje dzieckiem przez sugestie. Wyjaśnia i tłumaczy. Nie narzuca i nie wymuszania swojej woli. Niewątpliwie ojciec ukierunkowuje syna ${ }^{49}$. Oczekiwania ojca są dostosowane do możliwości syna. Co więcej, ojciec wyznacza je w oparciu o wzajemne ustalania i racjonalne podstawy ${ }^{50}$.

Ostatnią analizowaną postawą jest rozumna swoboda. Roman Bniński ma świadomość, że jego kontakty z synem są ograniczone ${ }^{51}$. Jednak oddalenie fizyczne, nie było w tym przypadku utratą więzi psychicznej z dzieckiem. Ojciec ma zaufanie do syna. Daje dziecku coraz szerszy zakres swobody. Jednak mimo tej swobody, troszczy sie o jego zdrowie. Bardzo ciekawy jest fragment jednego z listów, w którym ojciec przestrzega syna przed konsekwencjami zdrowotnymi picia piwa. Ojciec pisał: Kochany mój Romku, proszę cię na wszystko nie pij piwa. 1) zrobisz się otylym i ciężkim 2) rzecz skon-

na wakacje będzie niemożebny - Achilles przyda się tobie w górach, a i dla Hilarka wypadnie jakiegoś muca kupić" - ibidem, 9/21 Marca 1887 Czeremoszno.

${ }^{46}$ M. Ziemska, op. cit., s. 184.

${ }^{47}$ Ibidem, s. 185.

${ }^{48}$ Pisze: mój Romku, nie zaniedbuj i rób, bardzo akuratnie, co Dr każe, nic gorszego, jak te niby małe otłuczenia, jak się na nie zwraca uwagi - kochana Mama musi tem być zmartwioną i niespokojną, a ty już słuszny chłopak, sam więc dobrze się pilnuj” - Archiwum Obwodowe w Winnicy, Spuścizna rodziny Bnińskich, bez sygnatury, List Romana Bnińskiego do syna Romana Bnińskiego, 4/16 Marca [18]86 Czeremoszno.

${ }^{49}$ Pisał: „Noblesse oblige - a dziś o tem mało kto pamięta - i dla tego coraz gorzej na świecie, kochany mój Romku. Kto się dobrze nazywa, kto ma wcale dobrą tradycję rodzinną, ten nie pysznić się z tego powinien, ale starając się być zawsze na przodzie we wszystkiem własną pracą i własną zasługą, dawać innym dobry przykład i tym przykładem innych zachęcać, na dobrej utrzymywać drodze. Pamiętaj, kochany Romku, że im kto ma lepszą pozycję w towarzystwie, czy to z nazwiska, czy z majątku, tem mu ciężej na świecie, tem więcej ma obowiązków do spełniania, tem mniej może o sobie tylko, o swoich przyjemnościach myśleć, ale też za to więcej ma zasługi prawdziwej, lepszą zostawia po sobie pamięć. Dziś niestety przeciwnie dzieje się i dla tego powtarzam źle jest. Wstąpienie do szkoły publicznej, to pierwszy krok twój do życia publicznego, do świata w którem dobre miejsce mają prawo i obowiązek zajść. W gimnazjum spotkasz, naturalnie, kolegów, których sposób bycia, odrębny od tego, do którego przyzwyczajony jesteś, może nawet być przykrem dla ciebie, ale nie zrażaj się, mój Romku, z całą wyrozumiałością, pobłażliwością staraj się poznać charakter, serce kolegów, które często bardzo poczciwe przy bardzo nawet przykrej rubaszności i przy zupełnym braku ogłady salonowej. Na wielu przyjaciół nie licz, ale bądź dla wszystkich dobrym, poczciwym kolegą, bez różnicy stanu i pochodzenia: koleżeństwo to często zawiązek przyjaźni na całe życie - a w każdym razie, koleżeństwo wkłada na tych którym lepiej na świecie, szczerze i serdecznie pomagać tym, którym gorzej, trudniej i to pomagać przez całe życie, czy pieniędzmi, czy radą, czy stosunkami, byleby pomoc szła z serca, to ją każden przyjmie, a nikomu nie ubliży, nie drażni niczyjej godności, ani miłości własnej. $Z$ twoim poczciwem sercem łatwo to zrozumiesz i te twoimi czynnościami dobrze pokieruje" - ibidem, 28 Sierp[nia]/9 Wrześ[nia] 1885. Czeremoszno.

${ }^{50}$ M. Ziemska, op. cit., s. 185.

51 Pisał: „Nowego nic, oprócz smutku za wami” - Archiwum Obwodowe w Winnicy, Spuścizna rodziny Bnińskich, bez sygnatury, List Romana Bnińskiego do syna Romana Bnińskiego, brak daty, brak miejsca. 
statowana że nic tak nie psuje żoładka jak piwo: dowód Szaszkiewicza: Dorpatczycy - tu już tė przestaja pić piwo dla tych samych powodów, przy zmęczeniu potrzebujesz kieliszek wina, weź ze soba od nas z Krakowa, a przed Niemcami wythmacz się higiena le$k a r s k a^{52}$. Uzupełnieniem tego wywodu, była informacja zamieszczona w postscriptum kolejnego listu. Ojciec pisał: Czy pamiętasz o niepiciu piwa - to nie uprzedzenie - a rada lekarzy, którzy ogólnie odradzaja ten właśnie trunek, a jak pisałem, Dorpatczycy dowiedli o ile to źle na zdrowie wpływa $a^{53}$ i bezpieczeństwo. Dąży do unikania zagrożeń ${ }^{54}$. Potrafi ukierunkować dziecko ${ }^{55}$.

Relacje rodzinne - rozpatrywane poprzez pryzmat dziejów ziemiaństwa polskiego to obszar badawczy, który nie jest obcy historykom polskim. Na szczególną uwagę zasługuje tom wydany pod redakcją Cezarego Kuklo, zatytułowany Rodzina i gospodarstwo domowe na ziemiach polskich $w X V-X X$ wieku ${ }^{56}$. Jest to bowiem praca, która nie tylko ma wartość poznawczą (konstruuje obraz życia codziennego m.in. ziemiaństwa), ale również profiluje dalsze badania w tej tematyce. Szczególnie istotne jest właśnie kształtowanie dalszych badań, gdyż ostatnie dziesięciolecia zaowocowały nieprzeciętnym zainteresowaniem dziejami ziemiaństwa polskiego.

Odnowieniu i żywiołowemu wręcz rozwojowi podlegają badania i dociekania genealogiczne i heraldyczne. Znamienne, że uprawiają te dyscypliny nie tylko zawodowi historycy, ale całe rzesze amatorów, którzy dociekają korzeni swoich rodzin.

Zakrawa to na chichot historii, gdy zwrócimy uwage na motywacje powodujaca ów wzrost zainteresowania. Społeczeństwo, w przeważajacej większości wywodzace się z plebsu, pańszczyźnianych ongiś chłopów, drobnych rzemieślników czy kupców, zaczyna poszukiwać korzeni $w$ nadziei, że i ich przodkowie także należeli do stanu szlacheckiego. Okazuje się bowiem, że system kształcenia, dobór lektur szkolnych, a także wzory kultury szlacheckiej w nich przedstawiane, raczej postulowane aniżeli realizowane przez ten stan w praktyce spolecznej, nadal sa atrakcyjne. Po okresie pótwiecza, kiedy to oficjalna nauka i propaganda obciążaty warstwe szlachecka wszelkimi przywarami spolecznymi i grzechami politycznymi, z oskarżeniami o przyczynienie się do zguby Polski włacznie, nagle szlacheckie pochodzenie stało się źródtem pożąania. Mamy w tym zakresie do czynienia z pewnym fenomenem psychospołecznym. Plebejskie w swojej większości społeczeństwo zaczęło zyskiwać swoja podmiotowość w wyniku

52 Ibidem, 1/18 Października [18]89. Wacławówka.

53 Ibidem, 18/30 Paźdz[iernika] [18]89. Wacławówka.

${ }^{54}$ Pisał: „Podobno wybieracie się do Wieliczki, kochany Romciu, w czasie Świąt - nie chcę was pozbawiać tej przyjemności, ale tam jest jaka doroczna feta, pomyśl kochany Romku, czy przy wielkiej masie osób, będziecie mogli dobrze wszystko wiedzieć - i czy to wycieczka bezpieczna. Sami o tem pomyślcie, poradzicie się i zrobicie jak zechcecie i jak będziecie woleli aby tylko wesoło Święta przepędzić - każda dobra rozrywka potrzebna dla zdrowia i dla nauki - ibidem, 5 Maja Gastein.

55 Pisał: „Jak tam idzie z maturą? Czy nie zanadto uczysz się po nocach - pamiętaj, mój Romciu, że w 6. półroczu lepiej pozbyć się pewnych dziennych rozrywek, jak siedzieć po nocach - zdrowie na tem cierpi, a przy zmęczeniu ciała i umysłu, niewiele zostaje w pamięci” - ibidem, brak daty, brak miejsca. Vide: M. Ziemska, op. cit., s. 186.

56 Vide: Rodzina i gospodarstwo domowe na ziemiach polskich $w$ XV-XX wieku: struktury demograficzne, społeczne i gospodarcze, C. Kuklo (red.), Warszawa 2008. 

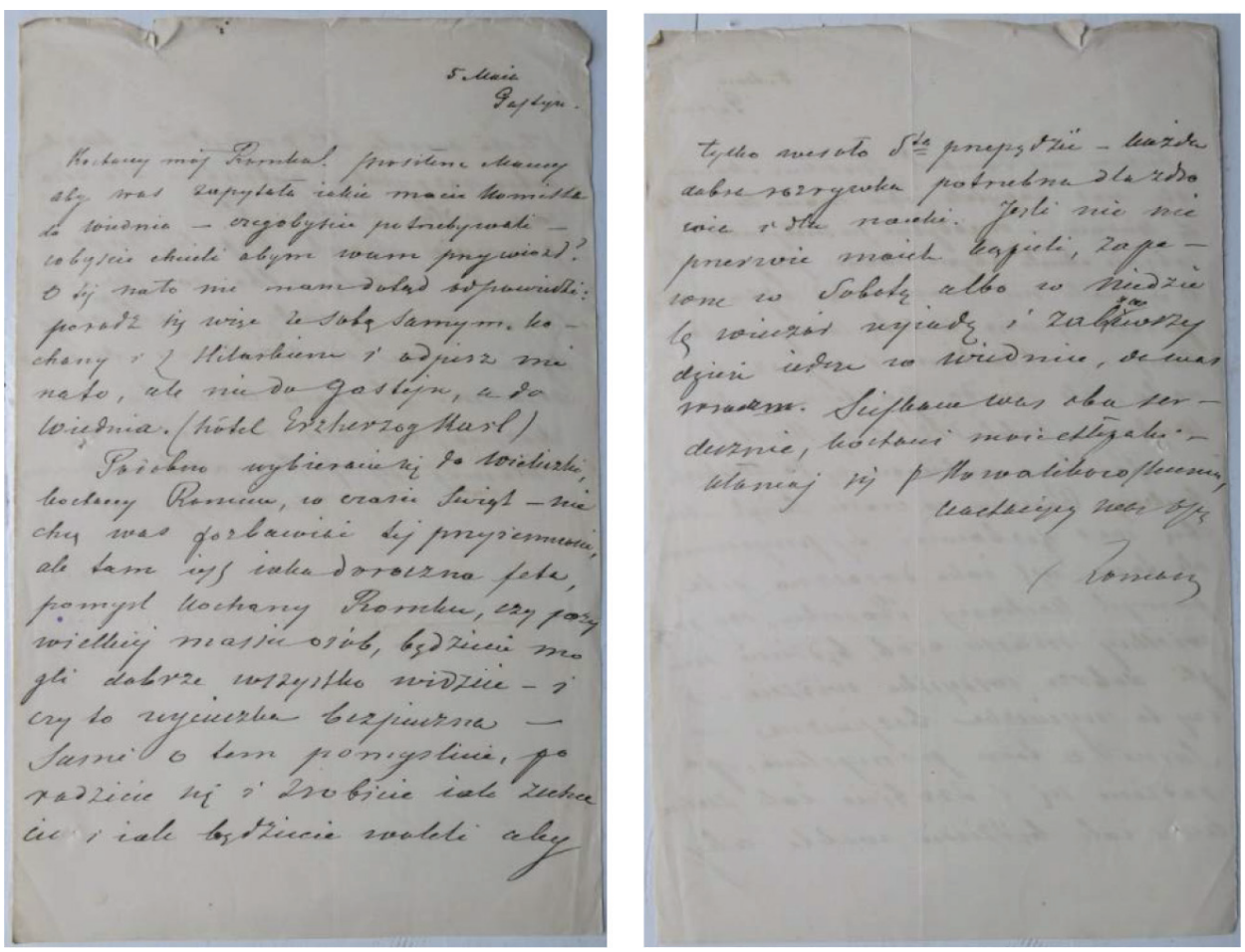

Fot. 7-8. List Romana Bnińskiego do syna

Źródło: Archiwum Obwodowe w Winnicy, Spuścizna rodziny Bnińskich, bez sygnatury, List Romana Bnińskiego do syna Romana Bnińskiego, 5 Maja Gastein

przemian $w$ strukturze i ruchliwości społecznej, wywołanych przez rewolucje polityczne. Awans materialny i społeczny, szczególnie po 1945 r., wynióst na stanowiska publiczne grupy ludzi o niskiej kulturze politycznej, które dotychczas nie uczestniczyly w sprawowaniu władzy. Po euforii wyniktej z poczucia władzy i ustabilizowaniu się systemu, przedstawiciele elit różnej rangi zaczęli poszukiwać uzasadnień swojej pozycji społecznej nie w ideologii marksistowskiej, ale uciekajac się do obcej sobie dotychczas tradycji. W ten sposób formuje się fantomowy system szlachecki, obejmujący zarówno szlachtę „z urodzenia”, jak i elity pochodzenia plebejskiego. Proces ten trwa nadal i należy mieć nadzieję, że $w$ nieokreślonej bliżej przyszłości społeczeństwo polskie, targane różnorakimi sprzecznościami, wypracuje powszechnie akceptowany system wartości; stanie się prawdziwie równe $i$ wolne, bez stosowania tożsamościowych protez $^{57}$.

57 A.J. Zakrzewski, K. Studnicka-Mariańczyk, Wprowadzenie, w: Rodzina, przyjaciele, sąsiedzi, znajomi. Fotografia jako źródło do dziejów ziemiaństwa w zbiorach Korabitów Ostrowskich z Maluszyna, t. I: Rodzina Ostrowskich $h$. Korab z Maluszyna w zbiorach fotografii z XIX $i$ XX wieku [tekst w posiadaniu autorów]. 
Zainteresowanie ziemiaństwem przekłada się na edycje materiałów źródłowych. Wśród nich wyjątkowy charakter mają dzienniki, pamiętniki oraz listy. Relacjonowały bowiem życie codzienne najbliższej rodziny. Ukazywały zatem: życie powszednie rodziny, stosunki w niej panujące, koligacje rodzinne, stosunki z sąsiadami, znajomymi i przyjaciółmi... Taki też charakter mają listy Romana Bnińskiego do syna. Tak jak wszystkie materiały o charakterze bezpośrednim, pozwalają zatem na konstruowanie nowego/bardziej szczegółowego obrazu ziemiaństwa. Obrazu skonfrontowanego ze stereotypowymi wyobrażeniami na jego temat, uformowanymi głównie w oparciu o literaturę pozytywistyczną i marksistowską ${ }^{58}$.

\section{Bibliografia}

Źródła archiwalne

Archiwum Obwodowe w Winnicy, Spuścizna rodziny Bnińskich, bez sygnatury.

\section{Literatura}

Epsztein T., Edukacja dzieci i młodzieży w polskich rodzinach ziemiańskich na Wotyniu, Podolu i Ukrainie w II połowie XIX wieku, Warszawa 1998.

Grabski A.F., Zarys historii historiografii polskiej, Poznań 2000.

Janik M., Bniński Roman (1826-1912), w: Polski słownik biograficzny, t. II, Kraków 1936.

Kwilecki A., Żywe jest zainteresowanie problematyka ziemiańska. Zamiast wstępu, w: Ziemiaństwo wielkopolskie. W kręgu arystokracji, A. Kwilecki (red.), Poznań 2004.

Korzeniowski M., Za Złota Bramą: działalność spoleczno-kulturalna Polaków w Kijowie w l. 1905-1920, Lublin 2009.

Minakowski M.J., Genealogia potomków Sejmu Wielkiego, http://www.sejm-wielki.pl/b/1.1122.113 [dostęp: 1.06.2018].

Minakowski M.J., Genealogia potomków Sejmu Wielkiego, http://www.sejm-wielki.pl/b/1.1122.117 [dostęp: 1.06.2018].

Miszczuk M., Bniński Roman Piotr herbu Łodzia (1869-1948), w: Harcerski słownik biograficzny, t. IV, J. Wojtycza (red.), Warszawa 2016.

Rodzina i gospodarstwo domowe na ziemiach polskich w XV-XX wieku: struktury demograficzne, społeczne i gospodarcze, C. Kuklo (red.), Warszawa 2008.

Sedlaczek S., Harcerstwo na Rusi i w Rosji: 1913-1920, Warszawa 1936.

Topolski J., Metodologia historii, Warszawa 1984.

Zakrzewski A.J., Studnicka-Mariańczyk K., Wprowadzenie, w: Rodzina, przyjaciele, sąsiedzi, znajomi. Fotografia jako źródto do dziejów ziemiaństwa w zbiorach Korabitów Ostrowskich z Ma-

58 Vide: J. Topolski, Metodologia historii, Warszawa 1984; A.F. Grabski, Zarys historii historiografii polskiej, Poznań 2000. 
luszyna, t. I: Rodzina Ostrowskich h. Korab z Maluszyna w zbiorach fotografii z XIX $i$ XX wieku [tekst w posiadaniu autorów].

Ziaja A., Wybrane przejawy aktywności społeczno-kulturalnej Polaków na Ukrainie Naddnieprzańskiej w okresie rzadów ukraińskiej Rady Centralnej (marzec 1917-kwiecień 1918), http://www. irekw.internetdsl.pl/aktywucr.html [dostęp: 1.06.2018].

Ziemska M., Postawy rodzicielskie i ich wptyw na osobowość dziecka, w: Rodzina i dziecko, M. Ziemska (red.), Warszawa 1980.

http://swiadomaedukacja.pl [dostęp: 18.07.2018]. 